\title{
New data on Myxomycetes of North-Eastern Russia
}

\author{
Anastasiya Soldatenkova ${ }^{1}$, Yana Baranova $^{2}$, Alina Alexandrova ${ }^{1}$, Andrey Matveev ${ }^{1}$, \\ Vladimir Gmoshinskiy ${ }^{1 *}$, and Anastasiya Vlasenko ${ }^{3}$ \\ ${ }^{1}$ Lomonosov Moscow State University, 119234, Moscow, Leninskie gory, 1-12, Russia \\ ${ }^{2}$ Novosibirsk State University, Novosibirsk, Pirogova st., 1, Russia \\ ${ }^{3}$ Central Siberian Botanical Garden SB RAS, 630090, Novosibirsk, Zolotodolinskaya st., 101, Russia
}

\begin{abstract}
Results of the study of species diversity of myxomycetes in North-Eastern Russia are presented. Moist chamber cultures were prepared with samples of leaf litter from Republic of Sakha (Yakutia) and Magadan oblast and with samples of bark from two sample plots in the vicinity of Yakutsk and Neryungri. A total of 49 species in 23 genera, 9 families, and 5 orders were recorded during the study.
\end{abstract}

\section{Introduction}

Myxomycetes (plasmodial slime molds) are a group of free-living protists belonging to Amoebozoa [1]. Their life cycle includes mobile trophic stages without hard cell wall, resting, and reproductive stages; the latter are represented various types of fruiting bodies. No regular studies of myxomycete communities of North-Eastern Russia were conducted to date. Magadan Oblast and Chukotka Autonomous Okrug are relatively well-studied: there were recorded 40 and 50 species, respectively [2-5]. In Republic of Sakha (Yakutia), two species were found before our study: Fuligo septica (L.) F.H. Wigg. [6] and Lycogala epidendrum (L.) Fr. [7]. The present study summarizes moist chamber data for Sakha for the first time and lists new findings for Magadan Oblast. Part of the results of the study was presented at the International science forum "Lomonosov" [8].

\section{Materials and methods}

Substrate samples for moist chambers were collected in the field from 09.08.2017 to 03.09.2017 on the territory of the Magadan Oblast and Republic of Sakha (Yakutia). Republic of Sakha: Megino-Kangalassky District. Vicinity of the village of Nizhniy Bestyakh, Lake Khotun-Manchyya: Loc 1 N 61.994631; E 129.953021; vicinity of the village of Nuoragana: Loc 2 N 62.130854; E 131.244468; Loc 3 N 62.129743; E 131.238443; . Churapchinsky District. Vicinity of the village of Tyolyoy-Diring. Loc $4 \mathrm{~N}$ 61.953266; E 132.135221. Tomponsky District. Buoya River Valley: Loc 5 62.704305; 134.059042; village of Megino-Aldan, Aldan River Valley: Loc 6 N 62.624475;

\footnotetext{
* Corresponding author: rubisco@list.ru
} 
E134.894308; Loc 7 N 62.629810; E 134.864554; Loc 8 N 62.630079; E 134.837007;

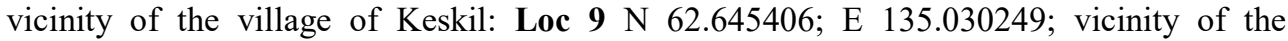
settlement of Rosomakha, Vostochnaya Khandyga River Valley Loc 10 N 63.048042; E 137.877877. Oymyakonsky District. The Ulu Lake: Loc 11 N 63.338564; E 141.080348; Loc 12 N 63.337761; E 141.084433; Loc 13 N 63.329077; E 141.055810. Staryi Kolymskii Trakt: Loc 14 N 63.341144; E 142.006310. Indigirka River Valley, vicinity of the village of Tomtor: Loc 15 N 63.380082; E 143.201637. Indigirka River Valley, vicinity of the village of Bereg-Yurdya: Loc 16 N 63.432195; E 142.975542; Loc 17 N 63.435802; E 142.972228; Loc 18 N 63.433884; E 142.966701. Staryi Kolymskii Trakt: Loc 19 N 63.207780; E 142.696013. Lugovaya River Valley, village of Kyubeme: Loc $20 \mathrm{~N}$ 63.472848; E 140.709991; Loc 21 N 63.475640; E 140.704486; Loc 22 N 63.477163; E140.708768; Loc 23 N 63.440071; E 140.635132. R504 Kolyma Highway, Zarya River: Loc 24 N 64.227409; E 141.487427. Vicinity of the urban-type settlement of Ust-Nera, Indigirka River Valley, Kutur-Yuryakh Stream: Loc 25 N 64.538746; E 143.075946. Yakutsk Urban Okrug. Western border of the city of Yakutsk: Loc 26 N 62.104846; E 129.680168. Neryungrinsky District. Southern part of the town of Neryungri: Loc $27 \mathrm{~N}$ 56.654151; E 124.75506. Magadan Region: Olsky Okrug. Vicinity of the village of Ola: Loc 28 N 59.572259; E 151.227739; Loc 29 N 59.572314; E 151.226691; Loc $30 \mathrm{~N}$ 59.565728; E 151.267087; Loc 31 N 59.568587; E 151.268850. Magadan Okrug. Vdovushka Island: Loc 32 N 59.495851; E 150.919274; Loc 33 N 59.496715; E 150.921509. Vicinity of the Staraya Vesyolaya stow: Loc 34 N 59.497850; E 150.908720.

Fragments of dry grass litter of last year (primarily Poaceae and Cyperaceae) were collected as a substrate in the localities 1-25 and 28-34. Sample plots were established in Loc 26 and 27; there, bark from 5 most abundant tree species was collected as a substrate (Pinus sp., Alnus sp., Popolus sp., Larix sp., Salix sp., and Betula sp.).

Substrate samples were collected in the sterile paper bags, where they were dried at room temperature without sunlight. This study presents the results of 261 experiments with moist chamber cultures: 187 with samples of bark and 74 with samples of grass litter.

Moist chamber cultures were performed according to the standard technique [9]. Petri dishes $10 \mathrm{~cm}$ in diameter were lined with filter paper, which was then wetted with water. The substrate fragments were distributed evenly on the Petri dish bottom so the entire surface could be observed. After the substrate fragments were placed in the chamber, it was wetted with excessive amount of water. The Petri dishes were checked on the second day, and excess water was either removed or added. Small amounts of water were added during the next waterings depending on a given substrate. The chambers were checked and watered at least every 10 days over the course of 3 months. During checks, fruit bodies from the moist chambers were mounted on paper tray using standard technique [10] and were placed in a matchbox in the herbarium. A species from single substrate was considered as a single specimen, even the substrate was placed in several moist chambers. Therefore, all fruit bodies of a given species that were found during all checks in all chambers were included in one specimen, even if content of the corresponding paper bag were distributed between two or more chambers [9].

Species were identified using dissecting microscopes (MBS-10, Carl Zeiss Stemi DV4, and Leica M-80) and microscopes (Micromed 3 var. 3 LED, Carl Zeiss Axiolab E, and Leica DM500). For specimen preparation, we used $4 \% \mathrm{KOH}$ solution. Generally accepted literature was used for species identification (including [11]).

Taxon authors are given in accordance with nomenclatural information system of Eumycetozoa [12]. In this study, we used the system of class Myxomycetes as proposed by C. Lado and U. Eliasson [13].

All collected specimens were deposited in the Myxomycetes collection of Department of Mycology and Algology, Faculty of Biology, Lomonosov Moscow State University 
(acronym MYX) and in Popov Herbarium of Central Siberian Botanical Garden, Siberian Branch of Russian Academy of Sciences (acronym NSK).

\section{Annotated list of species}

The list of species below is in alphabetical order. New species for Magadan Oblast are marked with "†"; for the Republic of Sakha, “*”.

*Arcyria cinerea Bull. Pers - 3 specimens. Loc: 16 [MYX 9170]; 26 [NSK 1030086].

*Badhamiopsis ainoae (Yamash.) T.E. Brooks et H.W. Keller - 1 specimen. Loc: 27 [NSK 1030107]. Previously, this species was only reported for the Astrakhan Oblast [14]. Its main special feature are the sparingly branched and heavily calcified capillitium. These tubes extend away from the peridium and are attached to the base of sporangium. After the dehiscence of sporangium, well noticeable tooth-like processes remain on the inner surface of peridium. It is believed that this species is widespread but does not occur in mass anywhere [15].

*Calomyxa metallica (Berk.) Nieuwl - 5 specimens. Loc: 5 [MYX 9193]; 16 [MYX 9168]; 17 [MYX 9166]; 19 [MYX 9161]; 26 [NSK 1030074].

Craterium leucocephalum (Pers. ex J. F. Gmel.) Ditmar in Sturm - 1 specimen. Loc: 33 [MYX 9427].

*Cribraria violacea Rex - 4 specimens. Loc: 1 [MYX 9200]; 4 [MYX 9194]; 10 [MYX 9184, MYX 9185]; 11 [MYX 9182, MYX 9183].

*Comatricha ellae Härk. - 4 specimens. Loc 26 [NSK 1030066; NSK 1030067; NSK 1030144; NSK 1030058].

*Comatricha nigra (Pers. ex J.F. Gmel.) J. Schröt. - 2 specimens. Loc: 26 [NSK 1030050]; 27 [NSK 1030033].

*Dianema mongolicum Novozh. - 2 specimens. Loc: 26 [NSK 1030109]; 27 [NSK 1030040]. In Russia, this rare species was reported previously for Altai [16, 17].

*Diderma chondrioderma (de Bary et. Rostaf.) Kuntze - 1 specimen. Loc: 25 [MYX 9148].

*Diderma effusum (Schwein.) Morgan - 2 specimens. Loc: 15 [MYX 9171, MYX 9174]; 21 [MYX 9159].

*Diderma montanum (Meyl.) Meyl. - 2 specimens. Loc: 15 [MYX 9172]; 21 [MYX 9159].

*Didymium anellus Morgan - 1 specimen. Loc: 22 [MYX 9157].

*Didymium dubium Rostaf. - 2 specimens. Loc: 2 [MYX 9197]; 22 [MYX 9156].

*Didymium melanospermum (Pers.) T. Macbr. - 1 specimen. Loc: 20 [MYX 9160].

*Didymium minus (Lister) Morgan - 1 specimen. Loc: 15 [MYX 9173].

*Didymium ochroideum G. Lister - 1 specimen. Loc: 9 [MYX 9187].

*Didymium squamulosum (Alb. et. Schwein.) Fr. - 7 specimens. Loc: 2 [MYX 9198]; 8 [MYX 9189]; 9 [MYX 9188]; 26 [NSK 1030073]; 27 [NSK 1030089]; 28 [MYX 9445]; 31 [MYX 9437].

*Echinostelium apitectum K.D. Whitney - 9 specimens. Loc: 26 [NSK 1030133; NSK 1030123; $\quad$ NSK 1030037; $\quad$ NSK 1030087; $\quad$ NSK 1030096; $\quad$ NSK 1030056; NSK 1030052; NSK 1030072]; 27 [NSK 1030032].

*Echinostelium fragile Nann.-Bremek. - 19 specimens. Loc: 26 [NSK 1030041; NSK 1030045; NSK 1030070; NSK 1030115; NSK 1030116; NSK 1030117; NSK 1030119; NSK 1030128; NSK 1030130]; $27 \quad$ [NSK 1030035; NSK 1030053; NSK 1030059; $\quad$ NSK 1030060; $\quad$ NSK 1030132; $\quad$ NSK 1030134; $\quad$ NSK 1030134; NSK 1030136; NSK 1030149]. 
*Echinostelium minutum de Bary - 7 specimens. Loc: 26 [NSK 1030079]; 27 [NSK 1030034; NSK 1030038; NSK 1030049]; 28 [MYX 9444]; 31 [MYX 9436]; 33 [MYX 9428].

*Enerthenema papillatum (Pers.) Rostaf. - 9 specimens. Loc: 26 [NSK 1030068; NSK 1030069; NSK 1030076; NSK 1030120; NSK 1030127; NSK 1030143].

$\dagger$ Hemitrichia leiotrichia (Lister) G. Lister in Lister - 1 specimen. Loc: 30 [MYX 9438; MYX 9439].

*†Hemitrichia pardina (Minakata) Ing - 2 specimens. Loc: 11; 18 [MYX 9164]; 28 [MYX 9443]; 31 [MYX 9435]; 34.

*Lamproderma scintallis (Berk. et. Broome) Morgan -1 specimen. Loc: 15 [MYX 9176].

*Leocarpus fragilis (Dicks.) Rostaf. - 3 specimens. Loc: 24 [MYX 9150]; 26 [NSK 1030101; NSK 1030110].

$\dagger$ Metatrichia floiformis (Schwein.) Nann.-Bremek - 1 specimen. Loc: 32 [MYX 9430].

*Licea biforis Morgan - 1 specimen. Loc: 27.

*Licea kleistobolus G.W. Martin - 6 specimens. Loc: 26 [NSK 1030065; NSK 1030094; NSK 1030099; NSK 1030100; NSK 1030106]; 27 [NSK 1030114].

*Licea minima Fr. - 1 specimen. Loc 26 [NSK 1030105].

*Licea operculata (Wingate) G.W. Martin - 3 specimens. Loc: 26 [NSK 1030071; NSK 1030084]; 27 [NSK 1030104].

*Macbrideola oblonga Pando et Lado - 1 specimen. Loc: 26 [NSK 1030122].

* Paradiacheopsis fimbriata (G. Lister et Cran) Hertel ex Nann.-Bremek. - 23 specimens. Loc: 26 [NSK 1030031; NSK 1030042; NSK 1030046; NSK 1030047; NSK 1030048; $\quad$ NSK 1030051; $\quad$ NSK 1030057; NSK 1030061; NSK 1030064; $\quad$ NSK 1030078; $\quad$ NSK 1030080; $\quad$ NSK 1030095; NSK 1030113; NSK 1030118; NSK 1030125; $\quad$ NSK 1030129; $\quad$ NSK 1030141; NSK 1030146; NSK 1030150]; 27 [NSK 1030036].

*Paradiacheopsis rigida (Brândza) Nann.-Bremek. $\quad-1$ specimen. Loc: 26 [NSK 1030091].

*Perichaena chrysosperma (Curr.) Lister - 1 specimen. Loc: 11[MYX 9181].

*†Perichaena corticalis (Batsch) Rostaf. - 9 specimens. Loc: 1 [MYX 9201]; 3 [MYX 9196]; 4 [MYX 9195]; 10 [MYX 9186]; 11 [MYX 9180]; 18 [MYX 9165]; 22 [MYX 9154; MXY 9155]; 28 [MYX 9442]; 31 [MYX 9434].

*Perichaena depressa Lib. - 3 specimens. Loc: 2 [MYX 9199]; 14 [MYX 9177]; 27 [NSK 1030077].

*†Perichaena pedata (Lister et. G. Lister) G. Lister ex E. Jahn - 4 specimens. Loc: 11; 13 [MYX 9178]; 19 [MYX 9162]; 34 [MYX 9425].

*Perichaena vermicularis (Schwein.) Rostaf. - 1 specimen. Loc: 1 [MYX 9202].

*Physarum bivalve Pers. - 7 specimens. Loc: 6 [MYX 9191; MYX 9192]; 12 [MYX 9179]; 23 [MYX 9151, MYX 9152; MYX 9153]; 25 [MYX 9146; MYX 9147]; 28 [MYX 9441]; 29 [MYX 9440]; 34 [MYX 9426].

*Physarum braunianum de Bary - 1 specimen. Loc: 26 [NSK 1030142]. In Russia, this species was only found in Novosibirsk Oblast [18]. Its most characteristic feature is the relatively small sessile orange sporangia with spores $8-12 \mu \mathrm{m}$ in diameter.

*Physarum cinereum (Batsch) Pers. - 3 specimens. Loc: 7 [MYX 9190]; 26 [NSK 1030043; NSK 1030112].

*†Physarum gyrosum Rostaf. - 1 specimen. Loc: 26 [NSK 1030054].

*Physarum notabile T. Macbr. - 1 specimen. Loc: 26 [NSK 1030039].

*†Stemonitopsis aequalis (Peck) Y. Yamam. - 2 specimens. Loc: 16 [MYX 9169]; 31 [MYX 9167]. 
*Symphytocarpus flaccidus (Lister) Ing et Nann.-Bremek. - 1 specimen. Loc: 26 [NSK 1030090].

*†Trichia botrytis (J.F. Gmel.) Pers. - 2 specimens. Loc: 19 [MYX 9163]; 31 [MYX 9432].

*Trichia contorta (Ditmar) Rostaf. - 2 specimens. Loc: 26 [NSK 1030148]; 27 [NSK 1030088].

$\dagger$ Trichia lutescens (Lister) Lister - 1 specimen. Loc: 31 [MYX 9431].

$\dagger$ Trichia munda (Lister) Meyl. - 1 specimen. Loc: 32 [MYX 9429].

\section{Discussion}

A total of 49 species from 23 genera, 9 families, and 5 orders were identified during this study with 261 moist chamber cultures. The highest number of species was in the orders Physarales (17 species) and Trichiales (15 species), compared to the number of species in the other orders: Stemonitidales (9 species), Cribrariales (5 species) и Echinosteliales (3 species). The highest number of species was noted in the genera Didymium (6 species), Physarum, Perichaena (5 species), and Trichia and Licea (4 species each).

A total of 9 species were added to the list of myxomycetes of Magadan Oblast, and 44 species were added to the list of myxomycetes of Sakha.

The results can be divided into two groups. As a result of 74 moist chamber cultures where grass litter was used as a substrate, 30 species were found. In 187 cultures with tree bark as a substrate, 25 species were found. However, only 6 species $(12 \%)$ formed fruit bodies on both types of substrate, indicating certain substrate preferences of most species we recorded. This result highlights the need for comprehensive studies of species diversity that would use for the moist chamber cultures all available substrates such as rotten wood, leaf litter, and dung of herbivores. Moist chamber culture technique along with the collection of specimens in the field are necessary for revealing the most complete morphospecies list of a given territory [9].

This work was supported by Moscow State University Grant for Leading Scientific Schools "Depository of the Living Systems" in frame of the MSU Development Program. The material was collected and identified as part of the State assignment of MSU, part 2 (topic number AAAA-A16116021660). The work A.V. Vlasenko was carried out as part of a State Task to the Central Siberian Botanical Garden, the Siberian Branch of the Russian Academy of Sciences; project AAAA-A17117012610055-3

\section{References}

1. S.M. Adl, D. Bass, C.E. Lane et al. J. Eukar. Mic. 66, 4-119 (2019)

2. Yu.K. Novozhilov, Nov. Sist. Nizs. Rast., 23, 143-146 (1986)

3. Yu. K. Novozhilov, M. Schnittler, S.L. Stephenson, Mikol. Fitopatol., 32. 18-29 (1998)

4. Yu.K. Novozhilov, M. Schnittler, Karstenia, 40. 117-122 (2000)

5. S.L. Stephenson, Yu.K. Novozhilov, M. Schnittler, J. Biogeogr. 27. 741-754 (2000)

6. D.A. Zhulidov, R.D. Robarts, A.V. Zhulidov, O.V. Zhulidova, D.A. Markelov, V.A. Rusanov, J.V. Headley, J. Environ. Qual. 31.1038-1042 (2002)

7. I.A. Petrenko, Macro- and micromycetes of Yakutia forests (Nauka, 1978)

8. A.A. Soldatenkova, New data on Myxomycetes of Yakutia and Magadan region, in Proceedings of the International science forum "Lomonosov-2019", Moscow, Russia (2019) 
9. A.V. Matveev, V.I. Gmoshinskiy, V.P. Prokhorov, Byulleten' Moskovskogo Obshchestva Ispytatelei Prirody Otdel Biologicheskii. 119, 36-45 (2014)

10. S. L. Stephenson, H. Stempen, Myxomycetes: A Handbook of Slime Molds (Timber Press, Inc., 2000)

11. M. Poulain, M. Meyer, J. Bozonnet. Les Myxomycétes. Tome 1, guide de determination (Fédération mycologique et botanique Dauphiné-Savoie, 2011)

12. C. Lado. An on line nomenclatural information system of Eumycetozoa. Real Jardín Botánico, CSIC. Madrid, Spain. http://www.nomen.eumycetozoa.com (2005-2020)

13. C. Lado, U. Eliasson. Taxonomy and Systematics: current knowledge and approaches on the taxonomic treatment of Myxomycetes. In: Myxomycetes: biology, systematics, biogeography, and ecology. Academic Press, 205-252. (2017)

14. I.V. Zemlyanskaya, Yu.K. Novozhilov, Myxomycetes. In: Condition and long-term changes of natural environment in Bogdinsko-Baskunchaksky Reserve, IPK "Tsaritsin", 155-163. (2012)

15. B. Ing, The myxomycetes of Britain and Ireland (The Richmond Publishing Co. Ltd., 1999)

16. Yu.K. Novozhilov, M. Schnittler, A.V. Vlasenko, K.A. Fefelov, Mikol. Fitopatol., 43, 522-534 (2009)

17. Yu.K. Novozhilov, M. Schnittler, A.V. Vlasenko, K.A. Fefelov, Mycotaxon, 11, 91-94 (2010)

18. A.V. Vlasenko, Yu.K. Novozhilov, Mikol. Fitopatol., 44, 99-108 (2010) 